"Factors related to succession planning in a government department in Gauteng"

\begin{tabular}{ll} 
AUTHORS & $\begin{array}{l}\text { Mpho Montlha Pila } \\
\text { Cecile Schultz } \\
\text { Leigh-Anne Paul Dachapalli }\end{array}$ \\
& $\begin{array}{l}\text { Mpho Montlha Pila, Cecile Schultz and Leigh-Anne Paul Dachapalli (2016). } \\
\text { Factors related to succession planning in a government department in Gauteng. }\end{array}$ \\
ARTICLE INFO & $\begin{array}{l}\text { Problems and Perspectives in Management, 14(4-1), 145-153. } \\
\text { doi:10.21511/ppm.14(4-1).2016.02 }\end{array}$ \\
\hline DOI & http://dx.doi.org/10.21511/ppm.14(4-1).2016.02 \\
\hline RELEASED ON & Friday, 23 December 2016 \\
\hline JOURNAL & "Problems and Perspectives in Management" \\
\hline FOUNDER & LLC “Consulting Publishing Company "Business Perspectives"
\end{tabular}

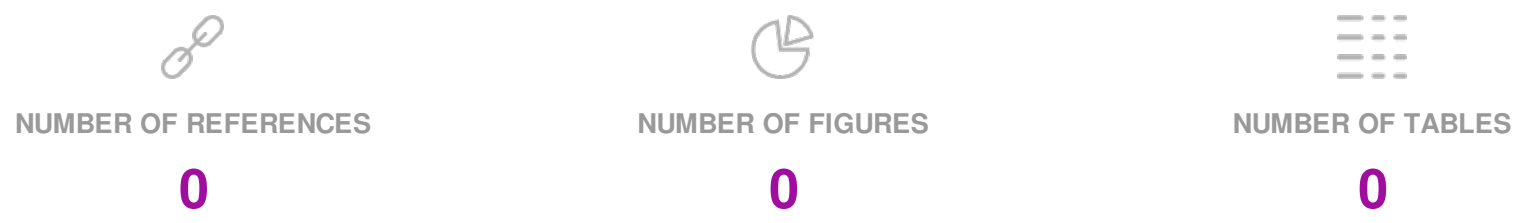

(C) The author(s) 2023. This publication is an open access article. 

Africa)

\title{
Factors related to succession planning in a government department in Gauteng
}

\begin{abstract}
One of the challenges facing government departments is the high loss of scarce-skilled employees. When examining departmental processes and procedures, observations were that the organization concerned was experiencing a leadership transition crisis in the absence of the implementation of succession planning. In order to ameliorate this challenge, it is prudent that research into factors and perception of employees on succession planning be conducted to assist with planning of retaining scarce skills and training of employees. A corresponding research study was performed to determine factors related to succession planning, the perceptions of employees and the way different demographic categories perceived succession planning.

The response rate of a questionnaire was $34.72 \%$. The items that loaded high were investigated for common themes and four factors emerged after factor analysis, namely organizational support programs, supervisor support, attraction of talent and a performance management system. The findings also indicated that there was a significant difference between groups in the organizational support program in terms of years of service and supervisor support among employees varying in position at the $5 \%$ level of significance. The most important implications for managers resulting from this study are that management development by way of succession planning contributes to employee satisfaction and improves the overall outcomes of the organization. Therefore, it can be recommended that there should be personal involvement by top and senior management in terms of personal accountability and responsibility for growing leaders and linking factors related to succession planning to organizational strategy and human resources strategy.
\end{abstract}

Keywords: succession planning, leadership, talent management, career management, training and development, performance management system.

JEL Classification: J21.

\section{Introduction}

The concept of succession planning has long been the subject of study in the private sector, but not in the public sector. Nevertheless, it is increasingly discussed in the public sector, and dangers of not having a succession planning mechanism in place are becoming apparent. Singh (2012) points out that succession planning is a subject of concern for managers worldwide as organizations face problems in filling critical positions where they need employees with a specific set of skills along with experience. According to Ahmadi, Sarlak, Mahdavi, Daraei and Vahidi (2012), succession planning is "a strategic process that reduces leadership or management gaps and gives opportunities for top talent to develop skills necessary for future roles". The absence of succession planning can hold back an organization as the demand for both the quantity and quality of talented employees will grow worldwide (Farashah, Nasehifar \& Karahrudi, 2011).

Although promotion is not always assured there will be a consistent supply of well-trained, experienced and motivated employees who are ready to step into

(C) Mpho Montlha Pila, Cecile Schultz, Leigh-Anne Paul Dachapalli, 2016. Mpho Montlha Pila, Master's Degree, Assistant Director, Department of Justice and Constitutional Development, South Africa.

Cecile Schultz, Ph.D., HRM, Associate Professor, Tshwane University of Technology, South Africa.

Leigh-Anne Paul Dachapalli, D.Admin, Senior Lecture, Tshwane University of Technology, South Africa. key positions (King, 2013). Furthermore, Perrenoud (2012) states that the shift in management is a serious point in the existence of an organization. Succession planning provides methods of retaining and developing individuals while transferring institutional knowledge (Rothwell, 2010).

If little emphasis is placed on the importance of grooming successors, it will not be surprising to find distressing uncertainty and detachment towards assuming leadership roles among young employees in the organization (Shamsuddin, Chan, Wahab \& Kassim, 2012). The best source of competitive advantage of an organization depends on its staff, as capable and talented employees represent a distinct and unique resource since they cannot be imitated by competitors (Beheshtifar \& Moghadam, 2011). The main study objective guiding the study reported on here was to determine the factors related to succession planning in a government department in Gauteng, South Africa.

\section{Literature review}

1.1. Clarification on the concept of succession planning. Rothwell (2010) defines succession planning as a "deliberate and systematic effort by an organization to ensure leadership continuity in key positions, retain and develop intellectual and knowledge capital for the future, and encourage individual advancement". Furthermore Farashah et al. (2011) agree that succession planning is a purpose- 
ful and systematic effort by an organization to ensure leadership stability in key positions, to retain and develop intellectual and knowledge capital for the future, and to encourage employee development.

According to Kim (2012), succession planning is "the deliberate use of mentoring, coaching and grooming of employees inside the organization identified as having the potential to advance when vacancies occur at senior executive level". Furthermore Galbraith, Smith and Walker (2012) state that succession planning describes the selection and training of internal employees for key leadership positions.

1.2. Factors related to succession planning. The literature review outlined five factors with four subfactors for each factor. A description of the five factors is given in the sections below.

1.2.1. Leadership. Transformational leadership forms part of a new leadership paradigm, and it fits the needs of today's work group, who wants to be inspired and empowered to succeed in times of uncertainties (Northouse, 2010). According to McLaggan, Bezuidenhout and Botha (2013), transformational leadership is effective in developing leaders, and is linked to the outcomes that most organizations, employees and leaders would value.

Transformational leadership theory fits into the succession planning equation (Hart, 2011, pp. 14-15). By having leaders who possess the characteristics of transformational leadership, namely idealized influence, inspirational motivation, intellectual stimulation and individualized consideration (Bass 1997, p. 133), the organization could see greater engagement in the process and the success of the program over time (Hart, 2011).

1.2.2. Talent management. Talent management is aligned to three main perspectives highlighted by Armstrong (2012), namely:

- exclusive employees - key employees with high performance or potential irrespective of position;

- exclusive position - the right employees in strategic jobs; and

- inclusive employees - every employee in the organization is regarded as actual or potential talent, given the opportunity and direction.

The sub-factors of talent management are talent attraction, talent development and talent retention, including the talent pool. Sastry (2013) elaborates by saying that by putting talent management into practice as a process that is transparent and equitable, it is expected to create an environment for employees to develop their skills in preparation for a range of future possibilities.
1.2.3. Career management. Career management and succession planning enable the organization to prepare its own goals and activities better (Hitka, Balazova \& Danihelova, 2012). Armstrong (2012) states that career management is complementary to management of succession planning as it aims to ensure that the organization has the flow of needed talent. Palade and Constantin (2012) note that career management is viewed as the ability to build a career, as an ongoing process of engaging in reflective, evaluative and decision-making processes using the skills for self-management and career building. The sub-factors in line with the present study are career planning, career counselling, mentoring and career development.

1.2.4. Training and development. Kumar (2013) argues that development is a training-related process. In this article, the term "training" is used to refer to both training and development. This is supported by Aguinis and Kraiger (2009) in their article, "Benefits of training and development for individuals, teams, organizations, and society".

Mirsepasi, Faghihi and Babaei (2013) state that developing human resources is a vital matter in the public and private sector in terms of a growing knowledge base and global economy. Rothwell (2010) holds that, when executing a systematic approach to succession planning, new knowledge and skills from internal talent are required, and adds that employee training is important so that employees may be effective and efficient in their new role. Training must therefore be a strategic priority and should be regarded as a resource for measuring and addressing skill shortages in an organization (Rajasekar \& Khan, 2013). The sub-factors of training and development are on-the-job training, coaching, e-learning and orientation.

1.2.5. Performance management. Yadav and Dabhade (2013) explain that performance management is a broad concept that entails understanding and acting on performance issues at each level of the organization, from employees to teams and departments and to the organization itself.

Armstrong (2011) highlights the following three theories underpinning performance management:

- Goal theory - places the emphasis on setting and agreeing on objectives against which performance can be measured and managed.

- Control theory - focuses the attention on feedback as a way of shaping behavior.

- Social cognitive theory - is based on the concept of self-efficacy where employees believe they can do or cannot do affects their performance. 
Performance planning, performance appraisal and performance development plans are sub-factors of performance management.

\section{Problem statement}

According to Koketso (2011), many public sector organizations have substantial uncertainties about leadership capabilities. Additionally, poor career planning and low levels of integration between the personal and professional aspirations of employees continue to persist for a variety of reasons, including succession planning. Kock and Burke (2008) concur that most public service organizations lack succession planning. Therefore, the present study aimed to determine the factors related to succession planning.

In support of the statement above, Wilkerson (2002) shows that research on succession planning is focused on the private sector, which leaves gaps in public sector practices of succession planning. Approximately 130 studies were conducted between 1980 and 1993, of which only five were conducted in public sector (Wilkerson, 2002).

\section{Research question and research objectives}

The main research question to be investigated was:

- What are the factors related to succession planning in a government department in Gauteng, South Africa?
In support of the main research question the two investigative questions were:

- Do employees perceive succession planning positively?

- How do different demographic categories perceive succession planning?

The fundamental research objectives were to determine:

- the factors related to succession planning;

- the perceptions of employees in relation to succession planning; and

- the way different demographic categories perceive succession planning.

\section{Research methodology}

4.1. Participants. The study used the Gauteng region and the national office of the department as the population. The research focused on professionally qualified, experienced specialists and middle, senior and top management employees. By 3 November 2014, the Gauteng offices alone employed 6610 employees. The questionnaire used to collect data was emailed to 550 participants, who completed it anonymously. Of these, 191 participants replied, which constituted a $34.72 \%$ response rate. Data were analyzed using both descriptive and inferential statistics. The biographical characteristics of the study population and sample are detailed below:

Table 1. Demographic data

\begin{tabular}{|c|c|c|c|c|c|c|c|c|c|c|}
\hline Gender & \multicolumn{2}{|r|}{ Male } & \multicolumn{2}{|c|}{ Female } & & & & & & \\
\hline Frequency & \multicolumn{2}{|r|}{84} & \multicolumn{2}{|c|}{107} & & & & & & \\
\hline Percentage & \multicolumn{2}{|r|}{$44 \%$} & \multicolumn{2}{|c|}{$56 \%$} & & & & & & \\
\hline Age & \multicolumn{2}{|r|}{$25<$} & \multicolumn{2}{|c|}{$26-35$} & \multicolumn{2}{|c|}{$36-45$} & \multicolumn{2}{|c|}{$46-55$} & \multicolumn{2}{|c|}{$56-65$} \\
\hline Frequency & \multicolumn{2}{|r|}{4} & \multicolumn{2}{|c|}{60} & \multicolumn{2}{|c|}{87} & \multicolumn{2}{|c|}{34} & \multicolumn{2}{|c|}{6} \\
\hline Percentage & \multicolumn{2}{|r|}{$2.1 \%$} & \multicolumn{2}{|c|}{$31.4 \%$} & \multicolumn{2}{|c|}{$45.5 \%$} & \multicolumn{2}{|c|}{$17.8 \%$} & \multicolumn{2}{|c|}{$3.1 \%$} \\
\hline Position & \multicolumn{2}{|c|}{ Senior management } & \multicolumn{2}{|c|}{$\begin{array}{l}\text { Specialist/middle } \\
\text { management }\end{array}$} & \multicolumn{2}{|c|}{$\begin{array}{l}\text { Technicians/junior manage- } \\
\text { ment/supervisors/foremen/sup } \\
\text { erintendents }\end{array}$} & & & & \\
\hline Frequency & \multicolumn{2}{|r|}{24} & \multicolumn{2}{|c|}{49} & \multicolumn{2}{|c|}{118} & & & & \\
\hline Percentage & \multicolumn{2}{|c|}{$12.6 \%$} & \multicolumn{2}{|c|}{$25.7 \%$} & \multicolumn{2}{|c|}{$61.8 \%$} & & & & \\
\hline $\begin{array}{l}\text { Place of } \\
\text { employment }\end{array}$ & $\begin{array}{l}\text { Chief } \\
\text { litigation } \\
\text { office }\end{array}$ & $\begin{array}{l}\text { Constitutional } \\
\text { development }\end{array}$ & $\begin{array}{l}\text { Corporate } \\
\text { services }\end{array}$ & $\begin{array}{l}\text { Court } \\
\text { services }\end{array}$ & $\begin{array}{l}\text { Legislative } \\
\text { development }\end{array}$ & $\begin{array}{l}\text { Master of the } \\
\text { High Court }\end{array}$ & $\begin{array}{l}\text { Chief } \\
\text { operation } \\
\text { office }\end{array}$ & $\begin{array}{l}\text { Director } \\
\text { general }\end{array}$ & $\begin{array}{l}\text { State law } \\
\text { advisor }\end{array}$ & Ministry \\
\hline Frequency & 6 & 9 & 112 & 16 & 4 & 13 & 15 & 7 & 5 & 1 \\
\hline Percentage & $3.1 \%$ & $4.7 \%$ & $58.6 \%$ & $8.4 \%$ & $2.1 \%$ & $6.8 \%$ & $7.9 \%$ & $3.7 \%$ & $2.6 \%$ & $0.5 \%$ \\
\hline $\begin{array}{l}\text { Years of } \\
\text { service }\end{array}$ & \multicolumn{2}{|c|}{$1-5$ years } & \multicolumn{2}{|c|}{$6-10$ years } & \multicolumn{2}{|c|}{$11-19$ years } & \multicolumn{2}{|c|}{ 20-29 years } & \multicolumn{2}{|c|}{$30+$ years } \\
\hline Frequency & & 78 & & & & & & & & \\
\hline Percentage & & $40.8 \%$ & & & & & & & & \\
\hline $\begin{array}{l}\text { Educational } \\
\text { level }\end{array}$ & Grade 12 & & Diploma or & ar degree & 4-year degree & & Master's d & & & \\
\hline Frequency & & 12 & & & & & & & & \\
\hline Percentage & & $8.9 \%$ & & & & & & & & \\
\hline
\end{tabular}

Most participants were females (56\%), while $44 \%$ were males. The majority of participants were be- tween the ages of 36 and $45(45.5 \%)$. The second leading group of participants were between the ages 
of 26 and 35 (31.4\%), trailed by those between the ages of 46 and $55(17.8 \%)$. The two lowest groups of participants were between the ages of 56 and 65 (3.1\%) and 25 and below (2.1\%). The majority of participants were technicians, junior management, supervisors, foremen and superintendents $(61.8 \%)$, followed by specialists and middle management $(25.7 \%)$ and senior management $(12.6 \%)$. Most of the participants were placed at corporate services $(58.6 \%)$. The other participants at branches were below $10 \%$; the lowest being the ministry $(0.5 \%)$. In terms of the number of years with the department under study, most participants $(0.8 \%)$ had been employed by the organization for a period of 1 to 5 years, followed by $31.9 \%$ of participants with 6 to 10 years of service. The third period was 11 to 19 years, with $19.9 \%$. The two lowest periods were 20 to 29 years $(5.8 \%)$ and $30+$ years $(1.6 \%)$. Lastly, the educational level of the largest single group (40.8\%) was a 4-year degree, followed by $36.1 \%$ of participants with a diploma or 3-year degree. The two smallest groups were $13.1 \%$ with a master's degree and $8.9 \%$ with Grade 12 .

4.2. Measuring instruments. To maximize validity, Cronbach's alpha coefficient was used to assess the internal consistency of items in a survey instrument to measure reliability (Cronbach, 1951). The Cronbach's alpha was above 0.70 for all the factors identified, which indicated good reliability. The questionnaire was given to 15 experts on succession planning to ensure face validity as recommended by Babbie (2008). The questionnaire was designed and verified by a statistician.

Furthermore, a factor analysis was done to measure construct validity. According to Saunders, Lewis and Thornhill (2009), construct validity refers to the extent to which the measurement questionnaire actually measures the presence of those constructs which the researcher intends to measure. A six-point Likert-type scale was used to measure the factors related to succession planning, where 1 was "strongly disagree" and 6, "strongly agree".

4.3. Research approach. A survey design with a quantitative approach was applied to this study in order to obtain sufficient data on the factors related to succession planning. Further, the purposive sampling method was used. According to Bless, HigsonSmith and Kagee (2006), in purposive sampling, a sample is chosen on the basis of what the researcher considers to be typical units. In the present study, the objective was to select units that were judged to be the most common among the study participants. The purposive sampling technique involved 550 employees in Gauteng. Permission to conduct research within a government department was obtained from the relevant deputy director general. Research participants agreed to take part in the research by filling in the consent form.

4.4. Data analysis. A factor analysis was conducted to investigate the grouping of items and their correspondence to initial theoretical scales (Field, 2009). A principal axis factor analysis with a direct oblimin rotation was used. The factor analysis was done to establish the factors with higher loadings from the questionnaire statements.

ANOVA was used to compare the differences between and within the demographic groups and to test for significant difference between the means. Comparisons were made between four factors (organizational support programs, supervisor support and performance management) using age, years of service and position.

\section{Results}

5.1. Factor analysis. The statements under each factor were actually the questions asked (Table 2).

Table 2. Four-factor analysis results

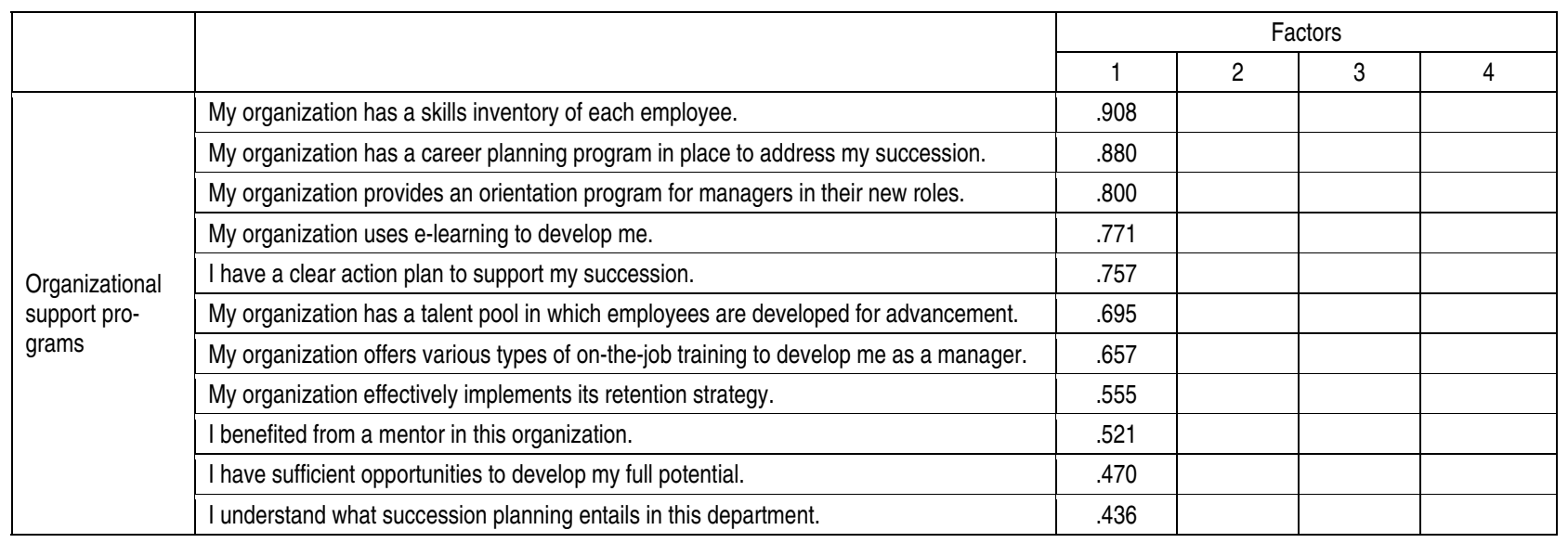


Table 2 (cont.). Four-factor analysis results

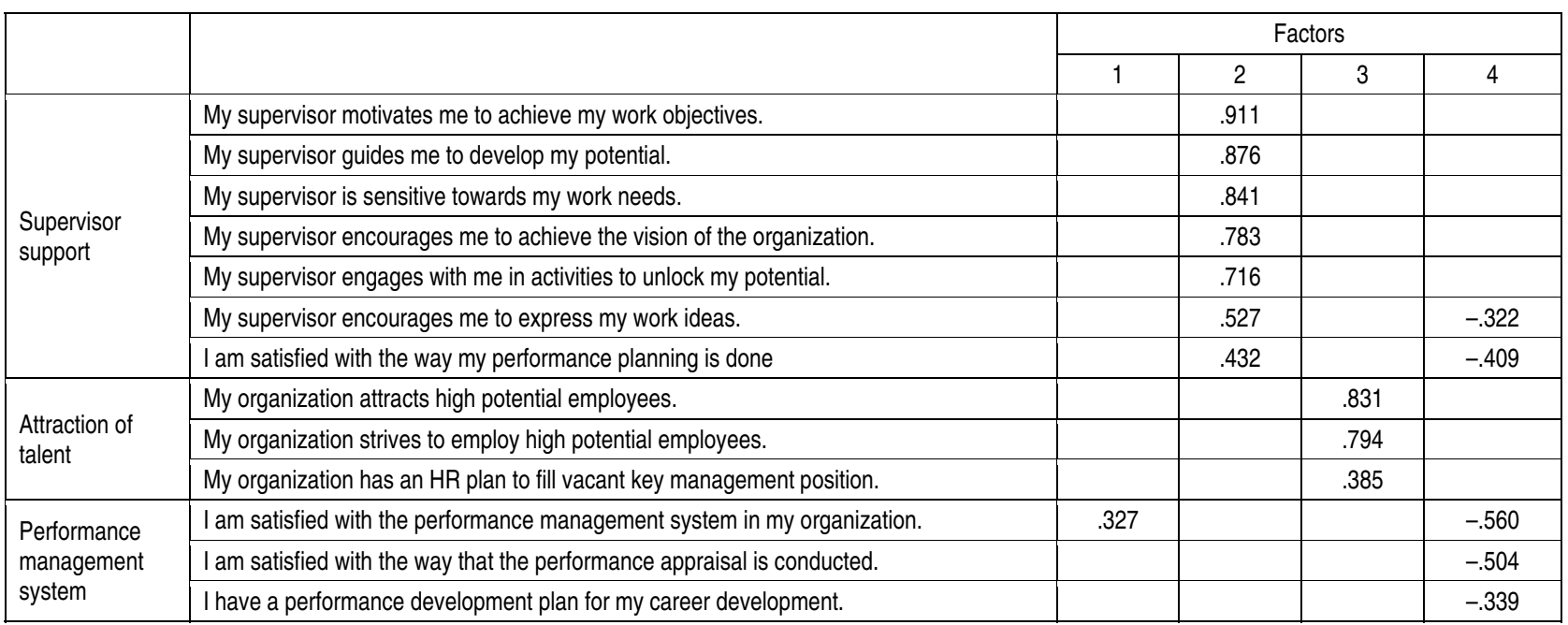

Source: authors' compilation based on survey results.

It was decided that the four-factor model would be best. The items that loaded high on each of the four factors were investigated for common themes. Table 2 reveals the four factors that emerged after the factor analysis, namely organizational support program (factor 1), supervisor support (factor 2), attraction of talent (factor 3) and performance management system (factor 4). Factor 2 is without item 13, which was moved to Factor 4 as it rather related to this factor.

5.2. Reliability analysis. Reliability analysis was executed for each of the four factors. Further, an item analysis was done for each scale. The four factors had a high reliability of above 0.70 , which indicated good reliability. Inter-item correlations were slightly higher than expected, but still not that much higher than 0.5 to be a cause for concern.

5.3. Descriptive statistics on the factors. The scores for each of the factors were created by calculating a mean score across all items comprising a scale. The table below illustrates the mean scores and standard deviation of each scale

Table 3. Descriptive per factor

\begin{tabular}{|l|c|c|c|c|c|}
\hline & $\mathrm{N}$ & Minimum & Maximum & Mean & Standard deviation \\
\hline Organizational support programs & 191 & 1.00 & 5.55 & 3.0233 & 1.12349 \\
\hline Supervisor support & 191 & 1.00 & 6.00 & 4.2855 & 1.10085 \\
\hline Attraction of talent & 191 & 1.00 & 6.00 & 4.3429 & 0.95470 \\
\hline Performance management system & 191 & 1.00 & 6.00 & 3.3674 & 1.26289 \\
\hline Valid N (list-wise) & 191 & & & & \\
\hline
\end{tabular}

Source: authors' compilation based on survey results

The participants indicated that they were 5.4. Analysis of variance (ANOVA). A one-way positive about supervisor support and ANOVA was used to investigate the relationship attraction of talent, followed by performance between categorical independent variables and an management system and organizational interval scale dependent variables. Demographic support programs. groups were thus compared on the four factors

Table 4. ANOVA in terms of age, years of service and position

\begin{tabular}{|l|l|c|c|c|}
\hline \multicolumn{1}{|c|}{ Dependent variable in terms of age } & & Mean square & $\mathrm{F}$ & Sig. \\
\hline Organizational support programs & Between groups & 1.816 & 1.445 & 0.238 \\
\hline Supervisor support & Between groups & 0.969 & 0.797 & 0.452 \\
\hline Attraction of talent & Between groups & 0.836 & 0.916 & 0.402 \\
\hline Performance management system & Between groups & 0.217 & 0.135 & 0.874 \\
\hline \multicolumn{1}{|c|}{ Dependent variable in terms years of service } & & Mean square & $\mathrm{F}$ & Sig. \\
\hline Organizational support programs & Between groups & 3.261 & 2.651 & $0.050^{\star \star}$ \\
\hline Supervisor support & Between groups & 0.504 & 0.412 & 0.745 \\
\hline Attraction of talent & Between groups & 0.396 & 0.431 & 0.731 \\
\hline Performance management system & Between groups & 0.952 & 0.593 & 0.620 \\
\hline
\end{tabular}


Table 4 (cont.). ANOVA in terms of age, years of service and position

\begin{tabular}{|l|l|c|c|c|}
\hline \multicolumn{1}{|c|}{ Dependent variable in terms of position } & & Mean square & $\mathrm{F}$ & Sig. \\
\hline Organizational support programs & Between groups & 3.287 & 2.650 & .073 \\
\hline Supervisor support & Between groups & 4.151 & 3.516 & $.032^{\star *}$ \\
\hline Attraction of talent & Between groups & .954 & 1.047 & .353 \\
\hline Performance management system & Between groups & .962 & .601 & .550 \\
\hline
\end{tabular}

Source: authors' compilation based on survey results.

Post hoc test

Post hoc Scheffe test assessed exactly where the difference lies in terms of years of service and position.

Table 5. Post hoc test in terms of years of service and position

\begin{tabular}{|c|c|c|c|c|c|}
\hline Dependent variable & (I) Years of service & (J) Years of service & Mean difference (I-J) & Standard error & Sig \\
\hline \multirow{12}{*}{$\begin{array}{l}\text { Organizational support } \\
\text { programs }\end{array}$} & \multirow{3}{*}{$1-5$ years } & $6-10$ years & 0.4726 & .18957 & .105 \\
\hline & & $11-19$ years & 0.4116 & .21942 & .321 \\
\hline & & $20+$ years & -0.0109 & .32193 & 1.000 \\
\hline & \multirow{3}{*}{$6-10$ years } & $1-5$ years & -0.4726 & .18957 & .105 \\
\hline & & $11-19$ years & -0.0611 & .22922 & .995 \\
\hline & & $20+$ years & -0.4835 & .32869 & .540 \\
\hline & \multirow{3}{*}{$11-19$ years } & $1-5$ years & -0.4116 & .21942 & .321 \\
\hline & & $6-10$ years & 0.0611 & .22922 & .995 \\
\hline & & $20+$ years & -0.4225 & .34676 & .686 \\
\hline & \multirow{3}{*}{$20+$ years } & $1-5$ years & 0.0109 & .32193 & 1.000 \\
\hline & & $6-10$ years & 0.4835 & .32869 & .540 \\
\hline & & $11-19$ years & 0.4225 & .34676 & .686 \\
\hline Dependent variable & (I) Position & (J) Position & Mean difference (I-J) & Standard error & Sig \\
\hline \multirow{6}{*}{ Supervisor support } & \multirow[b]{2}{*}{ Senior management } & $\begin{array}{ll}\begin{array}{l}\text { Specialist/ middle } \\
\text { management }\end{array} & \\
\end{array}$ & .3764 & .27071 & .382 \\
\hline & & $\begin{array}{l}\text { Technicians/junior manage- } \\
\text { ment/supervisors/foremen/su } \\
\text { perintendents }\end{array}$ & -.1126 & .24330 & .898 \\
\hline & \multirow[b]{2}{*}{ Specialist/middle management } & Senior management & -.3764 & .27071 & .382 \\
\hline & & $\begin{array}{l}\text { Technicians/junior manage- } \\
\text { ment/supervisors/foremen/su } \\
\text { perintendents }\end{array}$ & -.4891 & .18466 & $.032^{\star \star}$ \\
\hline & \multirow{2}{*}{$\begin{array}{l}\text { Technicians/junior manage- } \\
\text { ment/supervisors/foremen/sup } \\
\text { erintendents }\end{array}$} & Senior management & .1126 & .24330 & .898 \\
\hline & & $\begin{array}{l}\text { Specialist/middle } \\
\text { management }\end{array}$ & .4891 & .18466 & $.032^{\star *}$ \\
\hline
\end{tabular}

Source: authors' compilation based on survey results

The ANOVA in terms of age showed no significant difference (>0.05). The ANOVA in terms of years of service indicated a significant difference in organizational support programs; however, the post hoc Scheffé test indicated that the ANOVA was marginally significant but pair-wise comparisons of groups were not significant. It may thus be inferred that years of service did not show any relationship with the factors measured. The ANOVA in terms of position indicated a significant difference in supervisor support among employees varying in position at the 5\% level of significance. However, position in the organization did not influence the other factors of succession planning. Assessing exactly where the difference was, the post hoc Scheffé test reflected that specialists and middle management differed significantly from technicians, junior management/, supervisors, foremen or superintendents in terms of supervisor support received, with the latter exhibiting better confidence in supervisor support.

\section{Discussion}

6.1. Descriptive statistics of ranking question. The participants viewed leadership as extremely important. Danish, Aslam, Cheema and Hassan (2014) conducted research to determine the relationship between leadership behavior and its effect on organizational leadership. It was found that leadership behavior had a positive effect on employees' cognitive behavior. Managers of knowledge economy should therefore focus on leadership behavior that brings fruitful results for the organization.

Participants also perceived talent management, training and development as very important. Baqutayan (2014) highlights that an overwhelming number of human resource (HR) practitioners globally have reported that they believed talent management is a very important human capital challenge facing organizations as it is an important source of competitive advantage. Tahir, Yousafzai, 
Jan and Hashim (2014) emphasize that training and development are very important factors in HR management as it can improve performance at individual and organizational level. Additionally, learning has to be applied so that training and development can be important factors in HR management.

In the article by Guan, Zhou, Ye, Jiang and Zhou (2015), the results suggest that organizational career management is important for employees' objective and subjective career success. This is in line with participants' responses as they perceived that career management is important.

Even though participants viewed performance management as important, Hvidman and Andersen (2013) conclude that the outcome of performance management relies upon managers' use of performance information when they take action. The difference suggests that performance management would be less effective in public organizations.

Factors that emerged after factor analysis were identified as they showed high loadings.

6.2. Organizational support programs. The findings showed that employees had positive perceptions towards organizational support programs as these had an effect on employees' work behavior. Therefore, the organization involved in the study should be encouraged to make every effort to ensure that it always provides adequate support programs for its employees through a number of practices, i.e. being considerate of career goals, valuing contributions and providing assistance when needed. Lancaster and Di Milia (2014) agree that employees who observe that they are well supported by their organization reciprocate by performing better than those reporting lower levels of support. Contrary to positive perceptions of organizational support, Colakoglu, Culha and Atay (2010) found that perceived organizational support decreases employees' feelings of continuance commitment, which develops when employees are forced to stay with an organization because of the high cost of leaving.

6.3. Supervisor support. Participants showed positive perception of supervisor support as the supervisor helps employees to learn by encouraging, reinforcing and providing opportunities to grow in their career. Supportive supervisors are those who make themselves available to provide information, discuss how work should be done, talk through ideas that require clarification and acknowledge the subordinate's achievements.

Supervisor support is therefore crucial in the organization under study, as the supervisor is given a free hand to exercise the authority vested in him/her. A supervisor with supervisor support will definitely stimulate high employee performance. Gok, Karatuna and Karaca (2015) point out that having a supportive relationship with the supervisor increases job satisfaction, while organizational identification was found to be a significant part of this relationship. In other words, employees who received support from their supervisors better identified with the organization, which resulted in greater job satisfaction. Thus, the role of the supervisor in the development of an employee's career is vital.

6.4. Attraction of talent. Participants showed a positive perception of attraction of talent. As organizations seek talent, the talent seeks organizations. Although talent attraction is a door opener for talent management, it must be recognized that an organization cannot deliver service without the right talent. Rothwell (2010) states that it is not always clear who the right employees are, where the right places are and when those employees will be needed. To be relevant, recruitment strategies may need to be reinvented creatively if an organization is to increase the percentage of high potential it attracts. After all, all public service organizations rely on the same approach of recruitment (Form z83: a form to assist a government department in selecting a person for an advertised post). Globally, most organizations are focusing on e-recruitment using LinkedIn, Facebook and Twitter. Organizations are also improving their websites so that people may be attracted to apply for jobs online. Online attracts a higher quality, better educated and web-literate as jobs are advertised globally, locally or niche markets.

The present research indicated that managing talent is of strategic importance; therefore, one of the focus points of top management would be on fulfilling the expectations of potential employees and developing them through continuous learning, be it onthe-job or off-the-job training or career growth opportunities. Managers must exhibit strong leadership qualities and provide training and development initiatives for building the professional and personal competencies of employees as this would encourage employees to exert best efforts in their performance.

6.5. Performance management system. Participants showed positive perception of performance management. Ramulumisi, Schultz and Jordan (2015) agree that performance management acts as a link between organizational strategy and individual contributions and guarantees that the efforts of employees are harnessed to deliver organizational objectives. On the other hand, managers habitually fail to acknowledge their role in performance management and the fact that their own performance is dependent on the performance of subordinates. Therefore, managers should understand that a perfor- 
mance management system incorporates both formal and informal controls, and it plays a supportive role across a broad range of managerial activities, from strategic processes to daily, ongoing management. Performance management increases productivity and the morale in an organization, creating a culture where employees take responsibility for their training and development. A performance management system further enables employees to plan their own work. If it is implemented effectively and expectations are clarified, employees can focus on contributing to the objectives of the organization and to their personal growth and development.

Recommendations, managerial implications, limitations, future research and conclusions. The results reflected organizational support programs, supervisor support, attraction of talent and performance management system as factors related to succession planning in a government department in Gauteng, South Africa. Based on the study, it can be recommended that there should be personal involvement of top management in terms of personal accountability to grow leaders. The organization should develop and implement workforce transitioning plans, and invest in credible forecasting of what the future holds. Then it will become possible to diagnose accurately the skills and capabilities the organization will need in order to succeed.

The first implication for managers is the confirmation that having the factors related to succession planning linked to the objectives, and the career development process of the organization is the best approach to ensure that the right talent is readily available to fill vacant posts. Leadership and/or management development through succession planning contributes to employee satisfaction and improves the organization's overall outcomes.
Managers should be aware of the organization's work requirements and strengths as well as the weaknesses of its leadership. Most managers will disagree that it is easy for them to overlook weakness since the cause of the weakness may be rooted in their own past decisions. On the other hand, it is also easy for them to overlook strengths, which they may take for granted. This is destined to become an unfortunate course of action because managers fall prey to the gambler's fallacy specifically that more effort will lead to a big payoff. However, some efforts never pay off; they just lead to mounting losses. That is why organizations replace leaders after a string of repeated failures. To avoid this, managers should be aware of the human capital within the organization. Additionally, managers may be measured through their key performance indicators (KPIs) in terms of how many promotable employees they attract, develop and retain in their areas of responsibility.

The study revealed a need for additional research on succession planning and its effects on workforce planning. It would be beneficial for additional research to be conducted within public service organizations to determine the reasons for the loss of talent to competitors as there is the common practice of "thieving" of talent among public service. Furthermore, the research could be expanded by investigating the factors related to succession planning in other public service organizations as additional factors might surface. Moreover, a comparative study may be undertaken in future, comparing all provinces in South Africa to understand employees' perceptions and understanding of succession planning.

\section{References}

1. Aguinis, H. and Kraiger, K. (2009). Benefits of training and development for individuals and teams, organizations, and society, Annual Review of Psychology, 60, pp. 451-474.

2. Ahmadi, S.A.A., Sarlak, M.A., Mahdavi, M., Daraei, M.R. and Vahidi, T. (2012). Identifying the key factors in effective succession management and analyzing their impact rate at the Southern Khorasan Electric Energy Distribution Company (SKEDC), Interdisciplinary Journal of Research in Business, 2 (7), pp. 46-61.

3. Armstrong, M. (2011). Armstrong's handbook of strategic human resource management. 11th ed. London, Kogan Page, 308 p.

4. Armstrong, M. (2012). Armstrong's handbook of human resource management practice. 12th ed. London, Kogan Page, $1057 \mathrm{p}$.

5. Babbie, E. (2008). The basics for social research. Belmont, CA, Thompson, $550 \mathrm{p}$.

6. Baqutayan, S.M.S. (2014). Is talent management important? An overview of talent management and the way to optimise employee performance, Mediterranean Journal of Social Sciences, 5 (23), pp. 2290-2295.

7. Bass, B.M. (1997). Does the transactional-transformational leadership paradigm transcend organizational and national boundaries? American psychologist, 52 (2). 130-139.

8. Beheshtifar, M. and Moghadam, M.N. (2011). Studying the competency-related models in succession planning, European Journal of Economics, Finance and Administrative Sciences, 34 (34), pp. 113-121.

9. Bless, C., Higson-Smith, C. and Kagee, A. (2006). Fundamentals of social research methods: an African perspective. Cape Town, Juta, $190 \mathrm{p}$.

10. Colakoglu, U., Culha, O. and Atay, H. (2010). The effects of perceived organizational support on employees' affective outcomes: evidence from the hotel industry, Tourism and Hospitality Management, 16 (2), pp. 125-150. 
11. Cronbach, L.J. (1951). Coefficient alpha and the internal structure of tests, Psychometrika, 16 (3), pp. $297-334$.

12. Danish, R.Q., Aslam, N., Cheema, A.S. and Hassan, U. (2014). The impact of transformational leadership and employee commitment on organizational citizenship behavior, Science International, 26 (5), pp. 2451-2455.

13. Farashah, A.D., Nasehifar, V. and Karahrudi, A.S. (2011). Succession planning and its effects on employee career attitudes: study of Iranian governmental organizations, African Journal of Business Management, 5 (9), pp. 3605-3613.

14. Galbraith, Q., Smith, S.D. and Walker, B. (2012). A case for succession planning: how academic libraries are responding to the need to prepare future leaders, Library Management, 33 (4/5), pp. 221-240.

15. Gok, S., Karatuna, I. and Karaca, P.O. (2015). The role of perceived supervisor support and organizational identification in job satisfaction, Social and Behavioral Sciences, 177, pp. 38-42.

16. Guan, Y., Zhou, W., Ye, L., Jiang, P. and Zhou, Y. (2015). Perceived organizational career management and career adaptability as predictors of success and turnover intention among Chinese employees, Journal of Vocational Behavior, 88, pp. 230-237.

17. Hart, A.S. (2011). An in-depth evaluation of succession planning and management in health care organizations. Dissertation, University of Minnesota, $77 \mathrm{p}$.

18. Hitka, M., Balazova, Ž. and Danihelova, Z. (2012). Career management model for selected Slovak enterprise, $H u$ man Resources Management \& Ergonomics, 6, pp. 95-105.

19. Hvidman, U. and Andersen, C. (2013). Impact of performance management in public and private organizations, Journal of Public Administration Research and Theory, 24, pp. 35-58.

20. Kim, T.H. (2012). Succession planning in hospitals and the association with organizational performance, Nursing Economic, 30 (1), pp. 14-20.

21. King, G. (2013). Succession planning for your entire organization, New Hampshire Business Review, p. 18.

22. Kock, R. and Burke, M. (2008). Managing talent in the South African public service, Proquest Educational Journals, 37 (4), pp. 457-470.

23. Koketso, L.P. (2011). Perceived challenges to talent management in the South African public service: an exploratory study of the City of Cape Town Municipality. Dissertation, Cape Peninsula University of Technology, $142 \mathrm{p}$.

24. Kumar, K.A. (2013). Training and development practices and performance of SCCL, Training and Development, 1 (1), pp. 80-103.

25. Lancaster, S. and Di Milia, L. (2014). Organizational support for employee learning, European Journal of Training and Development, 38 (7), pp. 642-657.

26. McLaggan, E., Bezuidenhout, A. and Botha, C.T. (2013). Leadership style and organizational commitment in the mining industry in Mpumalanga, SA Journal of Human Resource Management, 11 (1), pp. 1-9.

27. Mirsepasi, N., Faghihi, A. and Babaei, M.R. (2013). Designing the systemic model of human resources development in the public sector, Advances in Environmental Biology, 7, pp. 519-526.

28. Northouse, P.G. (2010). Leadership theory and practice. Los Angeles, Sage, 435 p.

29. Palade, A. and Constantin, C. (2012). The necessity of counselling and vocational orientation in students' career management, Bulletin of the Transylvania University of Brasov. Series V: Economic Sciences, 5 (2), pp. 61-68.

30. Perrenoud, A. (2012). Effective succession planning in construction companies, Thesis: Master of Science, Arizona State University, $125 \mathrm{p}$.

31. Rajasekar, J. and Khan, S.A. (2013). Training and development function in Omani public sector organizations: a critical evaluation, Journal of Applied Business \& Economics, 14 (2), pp. 37-52.

32. Ramulumisi, T.V., Schultz, C.M. and Jordan, C.J. (2015). Perceived effectiveness of a performance management system, Journal of Contemporary Management, 12 (2015), pp. 517-543.

33. Rothwell, J.W. (2010). Effective succession planning: ensuring leadership continuity and building talent from within. New York, NY, 447 p.

34. Sastry, N.S.K. (2013). HR approaches to talent management, International Journal of Management Studies and Research (IJMSR), 1 (2), pp. 34-36.

35. Saunders, M., Lewis, P. and Thornhill, A. (2009). Research methods for business students, London, Pearson Education, $604 \mathrm{p}$.

36. Shamsuddin, A., Chan, C.-M., Wahab, E. and Kassim, A.S.M. (2012). Leadership management as an integral part of succession planning in HEIs: a Malaysian perspective, International Journal of Business and Social Sciences, $3(3)$, pp. 151-158.

37. Singh, M. (2012). Capacity development by talent management, Paper presented at the knowledge globalisation institute. Pune, India, 6, pp. 339-348.

38. Tahir, N., Yousafzai, I.K., Jan, S. and Hashim, M. (2014). The impact of training and development on employees' performance and productivity: a case study of United Bank Limited Peshawar City, KPK, Pakistan, International Journal of Academic Research in Business and Social Sciences, 4 (4), pp. 86-98.

39. Wilkerson, B. (2002). Effective succession planning: the public service imperative, Wisdownet globalization paper series, Human Resources Association, pp. 1-10.

40. Wilkerson, B. (2007). Effective succession planning in the public sector, Watson Wyatt Worldwide, pp. 1-7.

41. Yadav, R.K. and Dabhade, N. (2013). Performance management system in Maharatna companies (a leading public sector undertaking) of India: a case study of BHEL, Bhopal (MP), International Letters of Social and Humanistic Sciences, 4, pp. 49-69. 